\title{
Patent activity as an effect of the research and development of the business enterprise sectors in the countries of the European Union
}

\author{
Tomasz Sierotowicz \\ Jagiellonian University \\ Krakow, Poland \\ tomasz.sierotowicz@uj.edu.pl
}

\begin{abstract}
Patent activity is specified in the available literature as one of most common efthe relationship between $R \& D$ spending and patent activity at the mesoeconomic level, exemplified by the business enterprise sector. The scope of this article is to evaluate the efficiency of $R \& D$ expenditure from the patent activity point of view. The main research question is: does the efficiency of $R \& D$ expenditure, measured by the patent activity of the business enterprise sector, improve in the long term? The research covers 28 European Union countries. The conclusion is that increasing patent activity in the business enterprise sector, in the long term, depends on the management of $R \& D$ activities in entities belonging to that sector, rather than increasing $\mathrm{R} \& \mathrm{D}$ spending.
\end{abstract}

Received

March, 2015

1 st Revision:

June, 2015

Accepted:

July, 2015

Keywords: managing R\&D, intellectual property, comparative studies of countries

JEL classification: $\mathrm{O} 31, \mathrm{O} 32, \mathrm{O} 34, \mathrm{O} 39, \mathrm{O} 57$

\section{INTRODUCTION}

Innovation in businesses running $\mathrm{R} \& \mathrm{D}$ consists of innovation activities in all areas of socio-economic life (Stern, Porter \& Furman, 2000; DeGraff \& Quinn, 2007; Dyer, Gregersen \& Christensen, 2011). Continuous development of innovation, in turn, means expenditure and results of the R\&D activity. With regard to the obtained the R\&D activity results, two issues are of paramount importance: first, maintaining the continued development of innovation, which is made primarily in enterprises, universities and other entities carrying out R\&D activities; second, the effects obtained by these entities as a result of expenditure on R\&D activities (Okoń-Horodyńska, 2004).

Patent activity is one of the most frequently specified effects of $R \& D$ in the literature,and is measured by the number of assignees and inventors of granted patents (Simmine, 2003; Doloreux \& Parto, 2005; Verdes, 2006; Fichter \& Hintemann, 2010; Wisła, 2012, 2014; Schwab \& Sala-i-Martín, 2015). Investigations into the relationship between the changes in patent activity and the amount of expenditure on R\&D are not a novelty (Schmookler, 1951; Griliches, Pakes \& Hall, 1986; Griliches, 1990). The results of the current studies indicate that there is a strong correlation close to proportional dependency, particularly for large enterprises (Griliches, 1990). It can be concluded that the increase in the patent activity of large enterprises 
can be achieved in the long term by increasing expenditure on R\&D. However, the studies that have been carried out so far do not take into account analysis of the mesoeconomic level of national economies which can be exemplified by the business enterprise sector. The verification of this relationship is important for shaping the effective policy and strategy of national innovation development, where efficient R\&D spending is an important component. Based on the up-to-date research results presented in the literature, it can be assumed that the abovementioned relationship also occurs in the long term for the business enterprise sector. Hence, there are no empirical study results presented in the literature which proves that it is the correct assumption. The lack of empirical verification of this relationship provides the grounds for the formulation of the first and supplementary research question in this article,: does the increase of R\&D expenditure cause in the long term, an increase in the patenting activity of the business enterprise sector? Increase the $R \& D$ expenditure and patent activity concerns efficiency. Hence, the main discussion in this article is the dynamic change of R\&D expenditure efficiency incurred in the business enterprise sectors of the EU countries in terms of patent activity.

Effectiveness and efficiency are the two fundamental terms clearly defined in strategic management theory. They also refer to the management of R\&D activities and are becoming more important in particular when expenditure for this activity increases. It also concerns patent activity as one of the most often stated in the literature regarding the effects of $\mathrm{R} \& \mathrm{D}$ activity. While effectiveness is a complex issue related to making the right decisions and achieving various effects, the evaluation of efficiency requires the use of at least one input and one output variable (Davila, Epstein, Shelton, 2012). In this case, the input variable is the total intramural R\&D expenditure of the business enterprise sector and the output variable of the $\mathrm{R} \& \mathrm{D}$ is the number of entities belonging to the business enterprise sector that are assignees of patents granted by the European Patent Office (EPO) in a given research period. Hence the second, and main research question is as follows: does efficiency of $\mathrm{R} \& \mathrm{D}$ expenditure, measured by the patent activity of the business enterprise sector, improve in the long term? The main research goal consists of defining the differentiation of the efficiency levels of expenditure on R\&D in the patent activities of the business enterprise sectors of the EU countries.

\section{RESEARCH METHODOLOGY}

The research goals of this article are to determine the long-term relationship between the dynamics of changes in expenditure on $\mathrm{R} \& \mathrm{D}$ activities in the business enterprise sector, and the dynamics of changes in the number of entities in this sector obtaining patents granted by the EPO. The study involved the business enterprise sectors of $28 \mathrm{EU}$ countries in the period 1999-2013. Statistics of all assignees of patents granted by the EPO were used as input data in the empirical layer of the research, due to a unified procedure for obtaining a patent protection for each assignee, regardless of the country in which the business is run. However, the EPO database does not provide statistics on the number of entities that are assignees of patents granted by the EPO in the business enterprise sector of each EU country in the given research period. Hence, this work was performed before calculations. The data on the levels of $\mathrm{R} \& \mathrm{D}$ spending in the business enterprise sector was collated on the basis of data received from the Eurostat database. During the course of the study, a group of 10 leading countries, in terms of the number of patents granted by the EPO in the given research period was identified. For these countries the total intramural R\&D expenditure (GERD) of the business enterprise sector was comparatively assessed with the dynamics of changes in the number of enterprises in this sector that have obtained patents from the EPO in the long term. The acceptance of the 1999-2013 research period was determined by the completeness of the available raw data, which also implied the adoption of the annual observation interval. One weakness of the research results stems from the fact that using 
EPO patent protection is not mandatory. Hence, it can be concluded that inventive activity is a phenomenon of greater intensity than the researched patent activity of the business enterprise sector. Nevertheless, obtaining patent protection for major inventions is now an essential component of an intangible asset of any enterprise, despite the costs of maintaining patents.

Obtaining the value of the dynamics of changes required the selection of appropriate methods and computational tools. Since the long-term view is taken into account, as well as the dynamic changes of the R\&D expenditure amounts and the number of assignees belonging to the entities of the business enterprise sector were under research, the appropriate data series was prepared and the statistic tool must allow evaluation of the dynamic changes over a long period of time. According to the abovementioned research problem the average rate of change tool was selected. It is the classical descriptive statistic tool, typically used to evaluate changes in variables represented by data series in the long term (Triola, 2014; Freedman, Pisani \& Purves, 2007).

The research was carried out in three stages. The first stage involved identification of the number of entities that are assignees of patents granted by the EPO in the business enterprise sector of each of the 28 European Union countries in the given research period. Identification was carried out based on the name of the enterprise, the entity belonging to the business enterprise sector, indicated by the assignee specified in each patent record. This stage also allowed identification of a group of leading countries in the EU in terms of patent activity of the business enterprise sector since the country name is also indicated in the patent record. Thus, the subsequent stages of the research focused on this group of countries.

The second stage of the research consisted of calculating, for each country belonging to the newly appointed group, the dynamics of changes in the GERD of the business enterprise sector for the given country covered by the research, which is the input variable, and the dynamics of changes in the number of enterprises that are assignees of patents granted by the EPO belonging to the business enterprise sector of each country in the given research period, which is the output variable mentioned in the introduction. The calculations were performed using the average rate of change over the long term using the following equation (Triola, 2014; Freedman, Pisani \& Purves, 2007):

$$
\begin{gathered}
\log \bar{y}_{C}=\frac{1}{g-1} \sum_{i=2}^{g} \log \frac{y_{c i}}{y_{c i-1}} \\
A S_{C}=\left(\bar{y}_{C}-1\right) \times 100
\end{gathered}
$$

where:

$\bar{y}_{C}$ - geometric mean of the chain indices of the number of business enterprises that are assignees of the patents granted by the EPO and belong to the business enterprise sector of each country covered by the research,

$g$ - number of observations in the time series (corresponding to the number of years of the research period),

$i$ - next observation in the time series (corresponding to the number of business enterprises that are assignees of patents granted by the EPO in the given year for each country covered by the research),

c - another European Union country covered by the research,

$\frac{y_{c i}}{y_{c i-1}}-$ value of chain index,

$A S_{C}$ - average change rate in the patent activity of the business enterprise sector of each country covered by the research. 
Using the raw data of the Eurostat database, the dynamics of changes of total intramural R\&D expenditure of the business enterprise sector for the given country covered by the research were calculated. The calculations were performed using the average change rate over time, using the following equations (Triola, 2014; Freedman, Pisani \& Purves, 2007):

$$
\begin{gathered}
\log \bar{y}_{E}=\frac{1}{g-1} \sum_{i=2}^{g} \log \frac{y_{e i}}{y_{e i-1}} \\
\operatorname{Ard}_{E}=\left(\bar{y}_{E}-1\right) \times 100
\end{gathered}
$$

where:

$\bar{y}_{E}$ - geometric mean of the chain indices of the total intramural $\mathrm{R} \& \mathrm{D}$ expenditure of the business enterprise sector for the given country covered by the research,

$g$ - the number of observations in the time series (corresponding to the number of years of the research period),

$i$ - next observation in the time series (corresponding to the total intramural $\mathrm{R} \& \mathrm{D}$ expenditure of the business enterprise sector for the given country covered by the research, expressed in millions of euros),

$e-$ another European Union country under examination,

$\frac{y_{e i}}{y_{e i-1}}$ - the value of the next chain index,

$\operatorname{Ard}_{E}$ - the average rate of change in the total intramural R\&D expenditure of the business enterprise sector for the given country covered by the research in the research period.

The third stage of the research was to measure the effectiveness of $R \& D$ expenditure. The following procedure was used:

1. The calculation of the annual value of the number of patents (obtained from the EPO by enterprises belonging to the business enterprise sector and being assignees) per 1 million euros of the total intramural $\mathrm{R} \& \mathrm{D}$ expenditure of the business enterprise sector for the given country covered by the research in the research period.

$$
y r_{C i}=\frac{G P c_{i}}{R D c_{i}}
$$

where:

$R D c_{i}$ - the annual value of total intramural $\mathrm{R} \& \mathrm{D}$ expenditure of the business enterprise sector for the given country covered by the research in the research period [million euros],

$G P c_{i}$ - the annual number of patents (obtained from the EPO by enterprises belonging to the business enterprise sector and being assignees) of each country covered by the research, 
$y r_{C i}$ - the annual value of the number of patents (obtained from the EPO by enterprises belonging to the business enterprise sector and being assignees) per 1 million euros of the total intramural $\mathrm{R} \& \mathrm{D}$ expenditure of the business enterprise sector for the given country covered by the research, $c$ - another country covered by the research,

$i$ - next observation (corresponding to the number of years of the research period).

2. The use of the average change rate in the annual number of patent assignees per unit of R\&D expenditures for the business enterprise sector of each leading EU country (indicating a single observation in the time series), in the accepted research period, according to equations 6 and 7 (Triola, 2014; Freedman, Pisani \& Purves, 2007).

$$
\begin{aligned}
\log \overline{y a}_{c} & =\frac{1}{g-1} \sum_{i=2}^{g} \log \frac{y r_{C i}}{y r_{C i-1}} \\
E f_{c} & =\left(\overline{y a}_{c}-1\right) \times 100
\end{aligned}
$$

where:

$\overline{y a}_{c}$ - geometric mean of annual value of patents (obtained from the EPO by enterprises belonging to the business enterprise sector and being assignees) per 1 million euros of the total intramural $\mathrm{R} \& \mathrm{D}$ expenditure of the business enterprise sector of each country covered by the research,

$y r_{C i}$ - annual value of the number of patents (obtained from the EPO by enterprises belonging to the business enterprise sector and being assignees) per 1 million euros of the total intramural R\&D expenditure of the business enterprise sector for the given country covered by the research,

$g \quad$ - the number of observations in the time series (corresponding to the number of years of the research period),

i - next observation,

$c$ - another country covered by the research,

$\frac{A_{C i}}{A_{C i-1}}-$ value of the next chain relative index,

$E f_{c} \quad$ - average change rate of the annual value of the number of patents (obtained from the EPO by enterprises belonging to the business enterprise sector that are assignees) per 1 million euros of the total intramural $\mathrm{R} \& \mathrm{D}$ expenditure of the business enterprise sector of each country covered by the research.

The final results are obtained by comparing the calculated values of the average change rate. 


\section{RESEARCH RESULTS}

\subsection{SELECTION OF THE LEADING COUNTRIES OF THE EUROPEAN UNION IN TERMS OF PATENT ACTIVITY}

Patent statistics include, inter alia, the detailed information about assignees of patents granted by the EPO to EU countries. Table 1 shows the total number of assignees of patents granted by the EPO of each EU country. The percentage share of patent submission was calculated for each country.

Table 1

Total number of assignees of patents granted by EPO in 1999-2013

\begin{tabular}{|c|c|c|c|c|c|}
\hline 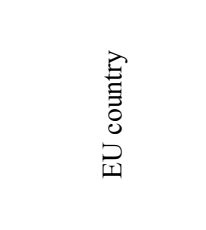 & 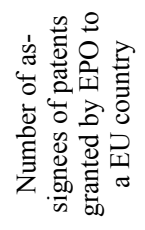 & 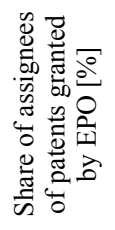 & 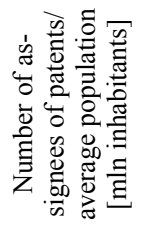 & 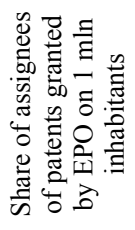 & 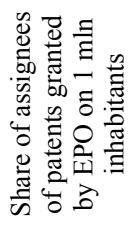 \\
\hline Malta & 3 & $0.00 \%$ & 0.40 & 7.42 & $0.06 \%$ \\
\hline Cyprus & 8 & $0.00 \%$ & 0.77 & 10.44 & $0.09 \%$ \\
\hline Lithuania & 20 & $0.01 \%$ & 3.27 & 6.12 & $0.05 \%$ \\
\hline Latvia & 38 & $0.01 \%$ & 2.21 & 17.20 & $0.15 \%$ \\
\hline Estonia & 44 & $0.01 \%$ & 1.35 & 32.53 & $0.27 \%$ \\
\hline Romania & 63 & $0.02 \%$ & 21.10 & 2.99 & $0.03 \%$ \\
\hline Slovakia & 88 & $0.02 \%$ & 5.39 & 16.34 & $0.14 \%$ \\
\hline Bulgaria & 90 & $0.02 \%$ & 7.67 & 11.73 & $0.10 \%$ \\
\hline Croatia & 130 & $0.04 \%$ & 4.32 & 30.07 & $0.25 \%$ \\
\hline Portugal & 195 & $0.05 \%$ & 10.47 & 18.63 & $0.16 \%$ \\
\hline Slovenia & 285 & $0.08 \%$ & 2.02 & 141.29 & $1.19 \%$ \\
\hline Luxembourg & 325 & $0.09 \%$ & 0.48 & 680.10 & $5.74 \%$ \\
\hline Greece & 333 & $0.09 \%$ & 11.06 & 30.10 & $0.25 \%$ \\
\hline Czech Republic & 548 & $0.15 \%$ & 10.33 & 53.06 & $0.45 \%$ \\
\hline Poland & 566 & $0.15 \%$ & 38.28 & 14.78 & $0.12 \%$ \\
\hline Hungary & 859 & $0.23 \%$ & 10.07 & 85.28 & $0.72 \%$ \\
\hline Ireland & 1006 & $0.27 \%$ & 4.24 & 237.25 & $2.00 \%$ \\
\hline Belgium & 2524 & $0.68 \%$ & 10.62 & 237.62 & $2.01 \%$ \\
\hline Spain & 4235 & $1.14 \%$ & 43.99 & 96.28 & $0.81 \%$ \\
\hline Denmark & 6051 & $1.64 \%$ & 5.46 & 1108.91 & $9.36 \%$ \\
\hline Austria & 7229 & $1.95 \%$ & 8.24 & 877.71 & $7.41 \%$ \\
\hline Finland & 7497 & $2.03 \%$ & 5.28 & 1419.36 & $11.98 \%$ \\
\hline Netherlands & 9392 & $2.54 \%$ & 16.36 & 574.24 & $4.85 \%$ \\
\hline Sweden & 16281 & $4.40 \%$ & 9.15 & 1779.65 & $15.03 \%$ \\
\hline Italy & 25243 & $6.82 \%$ & 58.25 & 433.33 & $3.66 \%$ \\
\hline United Kingdom & 46865 & $12.67 \%$ & 61.08 & 767.28 & $6.48 \%$ \\
\hline France & 62358 & $16.85 \%$ & 63.24 & 986.03 & $8.33 \%$ \\
\hline Germany & 177748 & $48.04 \%$ & 82.00 & 2167.70 & $18.30 \%$ \\
\hline Total & 370024 & $100 \%$ & 497.10 & 11843.45 & $100 \%$ \\
\hline
\end{tabular}

Source: Own calculation. 
As can be seen from the results in Table 1, taking into account only the participation of entities in the total number of assignees of patents granted by the EPO in the period 1999 to 2013, the largest percentage share was recorded for Germany, with $48.04 \%$, followed by France (16.85\%), the UK (12.67\%), Italy (6.82\%), Sweden (4.40\%), Netherlands (2.54\%), Finland (2.03\%), Austria (1.95\%), Denmark (1.64\%) and Spain (1.14\%). The remaining $18 \mathrm{EU}$ countries have a combined share of less than $2 \%$. On the other hand, taking into account the average population over the research period (table 1, column 6 ), the specified group of countries has been changed by replacing Spain with Luxembourg. Due to the research area, it is reasonable to leave Spain in the group of countries selected for further study, because the number of patent applicants in Spain is 4,235, while there are only 325 in Luxembourg. Therefore, it is assumed that the specified 10 countries constitute the leading group in EU patent activity (Table 2).

Table 2

The percentage share of assignees of patents granted by EPO to the leading countries of the European Union in 1999-2013

\begin{tabular}{|l|c|c|}
\hline \multicolumn{1}{|c|}{ EU country } & $\begin{array}{c}\text { Number of assignees of patents } \\
\text { granted by EPO to EU country }\end{array}$ & $\begin{array}{c}\text { Share of assignees of patents granted } \\
\text { by EPO [\%] }\end{array}$ \\
\hline Germany & 177748 & $48.04 \%$ \\
\hline France & 62358 & $16.85 \%$ \\
\hline United Kingdom & 46865 & $12.67 \%$ \\
\hline Italy & 25243 & $6.82 \%$ \\
\hline Sweden & 16281 & $4.40 \%$ \\
\hline Netherlands & 9392 & $2.54 \%$ \\
\hline Finland & 7497 & $2.03 \%$ \\
\hline Austria & 7229 & $1.95 \%$ \\
\hline Denmark & 6051 & $1.64 \%$ \\
\hline Spain & 4235 & $1.14 \%$ \\
\hline Total for EU leading countries & 362899 & $98.07 \%$ \\
\hline Total for other EU countries & 7125 & $1.93 \%$ \\
\hline Total & 370024 & $100 \%$ \\
\hline
\end{tabular}

Source: Own calculation.

The total share of assignees that are enterprises belonging to the business enterprise sector of each leading country that obtained patents from the EPO is $98.07 \%$ (Table 2). The remainder of the share, which is $1.93 \%$, constitutes business enterprises submitting patents from the other $18 \mathrm{EU}$ countries. The countries listed in Table 2 will be examined in terms of the relationship between the dynamics of changes in expenditure on $R \& D$ activities in the business enterprise sector and the patent activity of the entities of this sector.

\subsection{PATENT ACTIVITY OF THE BUSINESS ENTERPRISE SECTORS OF THE LEADING EU COUNTRIES}

Based on the patent statistics, the number of entities in the business enterprise sector of the leading countries of the EU has been established. The results are presented in Table 3. 
Table 3

The number of patents assignees belonging to the business enterprise sector, granted by EPO in $1999-2013$

\begin{tabular}{|c|c|c|c|c|c|c|c|c|c|c|}
\hline ¿ & 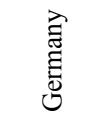 & 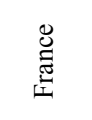 & 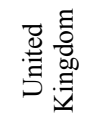 & 全 & $\begin{array}{l}\text { च्च } \\
0 \\
0 \\
0\end{array}$ & $\frac{\dot{d}}{\stackrel{0}{0}}$ & $\underset{\Xi}{\stackrel{\Xi}{\Xi}}$ & 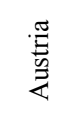 & 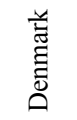 & 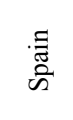 \\
\hline 1999 & 7217 & 2465 & 2434 & 909 & 597 & 448 & 327 & 246 & 193 & 79 \\
\hline 2000 & 5327 & 1862 & 1918 & 743 & 507 & 355 & 244 & 192 & 164 & 79 \\
\hline 2001 & 7938 & 2373 & 2041 & 856 & 691 & 447 & 320 & 303 & 201 & 104 \\
\hline 2002 & 10953 & 3143 & 3038 & 1258 & 1008 & 626 & 428 & 337 & 346 & 119 \\
\hline 2003 & 12878 & 3804 & 3756 & 1604 & 1386 & 730 & 563 & 405 & 450 & 201 \\
\hline 2004 & 13122 & 3376 & 3594 & 1595 & 1343 & 695 & 716 & 450 & 420 & 249 \\
\hline 2005 & 12172 & 2860 & 3103 & 1342 & 1139 & 509 & 553 & 404 & 363 & 227 \\
\hline 2006 & 13841 & 3395 & 3427 & 1575 & 1254 & 566 & 653 & 392 & 400 & 250 \\
\hline 2007 & 11043 & 3025 & 2865 & 1274 & 1187 & 506 & 498 & 320 & 336 & 225 \\
\hline 2008 & 12411 & 3469 & 2910 & 1535 & 1174 & 487 & 537 & 407 & 387 & 254 \\
\hline 2009 & 10423 & 2997 & 2448 & 1329 & 933 & 428 & 390 & 368 & 367 & 236 \\
\hline 2010 & 11156 & 3482 & 2452 & 1465 & 923 & 453 & 411 & 417 & 472 & 229 \\
\hline 2011 & 11555 & 3457 & 2575 & 1542 & 881 & 553 & 311 & 430 & 435 & 267 \\
\hline 2012 & 11189 & 3408 & 2660 & 1604 & 897 & 499 & 400 & 425 & 411 & 237 \\
\hline 2013 & 10969 & 3528 & 2539 & 1733 & 967 & 534 & 359 & 429 & 388 & 223 \\
\hline Total & 162194 & 46644 & 41760 & 20364 & 14887 & 7836 & 6710 & 5525 & 5333 & 2979 \\
\hline
\end{tabular}

Source: Own calculation.

The results were used to calculate the dynamics of changes in the number of business enterprises submitting patents granted by the EPO in the entire research period. Table 4 presents the results obtained using equations 1 and 2 .

Table 4

The average change rate of assignees of patents of the business enterprise sectors, granted by EPO to the leading EU countries in 1999-2013

\begin{tabular}{|c|c|c|c|c|c|c|c|c|c|c|}
\hline $\begin{array}{l}\hat{\theta} \\
\text { ठ }\end{array}$ & 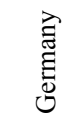 & 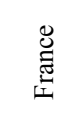 & 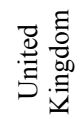 & 胥 & 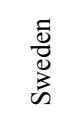 & 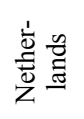 & 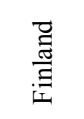 & $\underset{\stackrel{g}{E}}{\stackrel{0}{E}}$ & 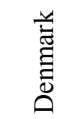 & $\begin{array}{l}\text { : } \\
\text { 员 }\end{array}$ \\
\hline $\begin{array}{c}\text { Average } \\
\text { change rate } \\
\mathrm{AS}_{\mathrm{C}}\end{array}$ & $\mathrm{AS}_{\mathrm{DE}}$ & $\mathrm{AS}_{\mathrm{FR}}$ & $\mathrm{AS}_{\mathrm{GB}}$ & $\mathrm{AS}_{\mathrm{IT}}$ & $\mathrm{AS}_{\mathrm{SE}}$ & $\mathrm{AS}_{\mathrm{NL}}$ & $\mathrm{AS}_{\mathrm{FI}}$ & $\mathrm{AS}_{\mathrm{AT}}$ & $\mathrm{AS}_{\mathrm{DK}}$ & $\mathrm{AS}_{\mathrm{ES}}$ \\
\hline $\begin{array}{c}\text { Average } \\
\text { change rate } \\
{[\%]}\end{array}$ & $3.04 \%$ & $2.59 \%$ & $0.30 \%$ & $4.72 \%$ & $3.50 \%$ & $1.26 \%$ & $0.67 \%$ & $4.05 \%$ & $5.11 \%$ & $7.69 \%$ \\
\hline
\end{tabular}

Source: Own calculation. 
The results from the calculations show that in all of the leading countries of the EU covered by the research, the average change rate of the number of businesses enterprises submitting patents granted by the EPO in the entire research period is increasing. The largest increase was recorded in Spain, where the number of companies submitting patents granted by the EPO increased throughout the research period from year to year by an average of $7.69 \%$. The smallest increase was recorded in the UK, where the number of business enterprises submitting patents granted by the EPO increased throughout the research period from year to year by an average of $0.30 \%$.

Answering the research question and achieving the first research goal requires a calculation of the average change rate of the expenditure on $R \& D$ in the business enterprise sectors of the leading EU countries.

\subsection{DYNAMIC CHANGE OF EXPENDITURE ON R\&D IN THE BUSINESS ENTERPRISES SECTORS OF THE LEADING EU COUNTRIES}

Based on data from the Eurostat database, the annual value of expenditure on $R \& D$ in the business enterprise sectors of the leading EU countries is presented in Table 5.

Table 5

Total intramural R\&D expenditure of the business enterprise sectors of the selected EU countries in $1999-2013$

\begin{tabular}{|c|c|c|c|c|c|c|c|c|c|c|}
\hline 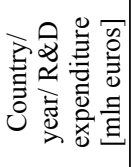 & $\begin{array}{l}\hat{\mathbb{E}} \\
\text { E्ञ } \\
\stackrel{0}{0}\end{array}$ & 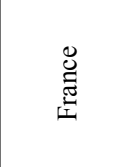 & 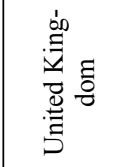 & 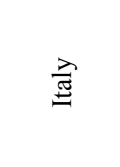 & 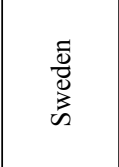 & 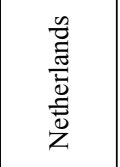 & 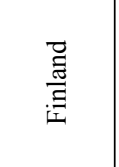 & 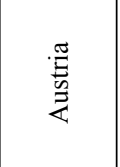 & 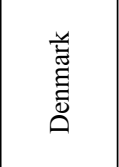 & $\begin{array}{l}\text { : } \\
\text { ڤึ }\end{array}$ \\
\hline 1 & 2 & 3 & \begin{tabular}{|l|}
4 \\
\end{tabular} & 5 & 6 & \begin{tabular}{|l|}
7 \\
\end{tabular} & \begin{tabular}{|l|}
8 \\
\end{tabular} & \begin{tabular}{|l|}
9 \\
\end{tabular} & \begin{tabular}{|l|}
10 \\
\end{tabular} & 11 \\
\hline 1999 & 33622.55 & 18655.13 & 17157.79 & 5684.00 & 6466.48 & 4263.00 & 2643.93 & 3343.68 & 2306.65 & 2597.10 \\
\hline 2000 & 35600.00 & 19348.42 & 18883.70 & 6239.00 & 7292.36 & 4458.00 & 3135.94 & \begin{tabular}{|l|}
3343.68 \\
\end{tabular} & \begin{tabular}{|l|}
2596.13 \\
\end{tabular} & 3068.99 \\
\hline 2001 & 36331.90 & 20782.15 & 19260.33 & 6660.90 & 8118.25 & 4712.00 & 3284.00 & \begin{tabular}{|l|}
3343.68 \\
\end{tabular} & 2934.22 & 3261.03 \\
\hline 2002 & 36950.00 & 21838.67 & 19829.99 & 7056.50 & 8002.10 & 4543.00 & 3375.11 & \begin{tabular}{|l|l|}
3130.88 \\
\end{tabular} & 3198.17 & 3926.34 \\
\hline 2003 & 38029.00 & 21646.18 & 18319.08 & 6979.00 & 7885.95 & 4804.00 & 3527.93 & \begin{tabular}{|l|}
3343.68 \\
\end{tabular} & 3354.84 & 4443.44 \\
\hline 2004 & 38363.00 & 22523.38 & 18664.95 & 7293.00 & \begin{tabular}{|l|}
7667.22 \\
\end{tabular} & 5071.00 & 3683.47 & 3556.48 & 3331.82 & 4864.93 \\
\hline 2005 & 38651.04 & 22503.13 & 19464.17 & 7855.80 & \begin{tabular}{|l|}
7724.57 \\
\end{tabular} & 5169.00 & 3876.90 & 4207.67 & 3476.76 & 5485.03 \\
\hline 2006 & 41148.00 & 23910.57 & 20985.18 & 8210.30 & 8753.78 & 5480.00 & 4107.79 & \begin{tabular}{|l|}
4448.68 \\
\end{tabular} & 3627.56 & 6557.53 \\
\hline 2007 & 43034.00 & 24752.72 & 22841.87 & 9454.70 & 8470.40 & 5495.00 & 4513.36 & 4845.86 & 4101.88 & 7453.90 \\
\hline 2008 & 46073.00 & 25761.21 & 19962.39 & 10173.30 & 9119.00 & 5263.00 & 5101.99 & 5232.63 & 4683.75 & 8073.52 \\
\hline 2009 & 45275.00 & 26425.93 & 17537.32 & 10238.10 & 7472.01 & 4900.00 & 4847.16 & \begin{tabular}{|l|}
5092.90 \\
\end{tabular} & 4930.61 & 7567.60 \\
\hline 2010 & 46929.00 & 27454.57 & 18730.94 & 10579.20 & 8160.17 & 5218.00 & 4854.46 & 5520.42 & 4755.09 & 7506.44 \\
\hline 2011 & 51077.20 & 28850.60 & 20057.84 & 10825.30 & 8986.36 & 6825.64 & 5047.43 & 5692.84 & 4870.27 & 7396.37 \\
\hline 2012 & 53790.10 & 30070.50 & 21095.94 & 11107.20 & 9416.60 & 7286.00 & 4695.00 & 6130.76 & 4977.74 & 7094.28 \\
\hline 2013 & 55952.00 & 30538.00 & 21149.30 & 10906.30 & 9545.51 & 7331.70 & 4602.40 & 6241.67 & 5058.30 & 6946.99 \\
\hline
\end{tabular}

Source: Eurostat Database, available at http://ec.europa.eu/eurostat, (Retrieved: 01.31.15).

The values presented in Table 5 show the empirical data used for calculating the average change rate of expenditure on R\&D in the business enterprise sectors of the EU countries under examination. Table 6 presents the results of the calculations that were carried out based on equations 3 and 4 . 
Table 6

The average change rate of total intramural $\mathrm{R} \& \mathrm{D}$ expenditure in the business enterprise sectors of the selected EU countries in 1999-2013

\begin{tabular}{|c|c|c|c|c|c|c|c|c|c|c|}
\hline 总 & 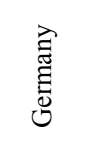 & 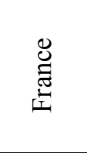 & 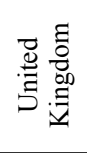 & 离 & $\begin{array}{l}\frac{1}{0} \\
\frac{0}{3} \\
\text { is }\end{array}$ & 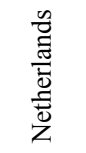 & $\underset{\text { 导 }}{\stackrel{\Xi}{\Xi}}$ & 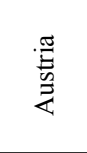 & 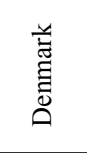 & $\begin{array}{l}\text { 范 } \\
\text { की }\end{array}$ \\
\hline $\begin{array}{c}\text { Average } \\
\text { change rate } \\
\text { Ard }_{\mathrm{E}}\end{array}$ & $\operatorname{Ard}_{\mathrm{DE}}$ & $\operatorname{Ard}_{\mathrm{FR}}$ & $\operatorname{Ard}_{\mathrm{GB}}$ & $\operatorname{Ard}_{\mathrm{IT}}$ & $\operatorname{Ard}_{\mathrm{SE}}$ & $\operatorname{Ard}_{\mathrm{NL}}$ & $\operatorname{Ard}_{\mathrm{FI}}$ & $\operatorname{Ard}_{\mathrm{AT}}$ & $\operatorname{Ard}_{D K}$ & $\operatorname{Ard}_{\mathrm{ES}}$ \\
\hline $\begin{array}{c}\text { Average } \\
\text { change rate } \\
{[\%]}\end{array}$ & $3.70 \%$ & $3.58 \%$ & $1.51 \%$ & $4.76 \%$ & $2.82 \%$ & $3.95 \%$ & $4.04 \%$ & $4.56 \%$ & $5.77 \%$ & $7.28 \%$ \\
\hline
\end{tabular}

Source: Own calculation.

The calculations show that in all of the leading countries in the EU the average change rate of the expenditure on $\mathrm{R} \& \mathrm{D}$ in the business enterprise sector, throughout the entire research period, is increasing. The highest increase was recorded in Spain, where the amount of expenditure on R\&D increased throughout the research period, from year to year, by an average of $7.28 \%$. The lowest increase was recorded in the UK, where the amount of expenditure on R\&D increased throughout the research period, from year to year, by an average of $1.51 \%$.

\subsection{THE EFFICIENCIES OF EXPENDITURE ON R\&D IN THE BUSINESS ENTERPRISE SECTORS OF THE LEADING EU COUNTRIES}

The values shown in Tables 3 and 5 are the input data for the calculation of the efficiency levels of expenditure on $R \& D$ in the business enterprise sectors of the EU countries included in the research. They were used to calculate the annual number of patent assignees per 1 million euros of expenditure on R\&D in the business enterprise sectors of each analysed country, which corresponds to the $y r_{C i}$ variable, calculated in equation 5 . These figures were then used to calculate the arithmetic mean of the number of patent assignees per 1 million euros of the total intramural expenditure on R\&D in the business enterprise sectors in each country covered by the research, for the entire period (according to equation 5); and the average change rate of the number of patent assignees per 1 million euros of expenditure on R\&D in the business enterprise sector in each country covered by the analysis, in the entire research period (according to dependencies 6 and 7). The calculated values of the arithmetic mean are shown in Figure 1. 


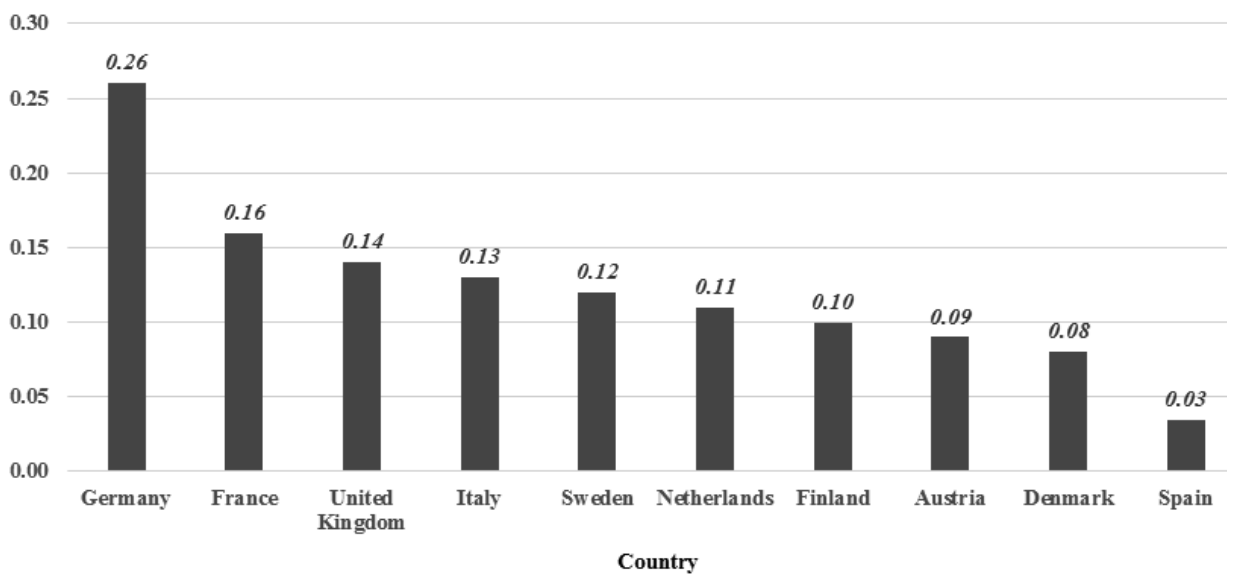

Figure 1. The average number of patents per 1 million euros of expenditure on R\&D in the business enterprise sector of the leading EU countries for the period 1999-2013

Source: Own calculation.

On the basis of the calculations, it was found that Germany has the highest value of 0.26 of patents granted by enterprises per 1 million euros of the total intramural expenditure on R\&D in the business enterprise sector across the research period, while the lowest value is in Spain, at 0.03 . The conclusion is that the creation of patents in the business enterprise sector in Germany is on average more than eight times less expensive than in Spain. Table 7 presents the results that were obtained using equations 6 and 7.

Table 7

The average change rate of the number of patent assignees per volume of $R \& D$ expenditure in business enterprises sectors in the leading EU countries

\begin{tabular}{|c|c|c|c|c|c|c|c|c|c|c|}
\hline$\stackrel{己}{\Xi}$ & 壳 & 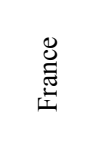 & 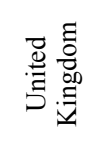 & $\underset{\Xi}{\Xi}$ & 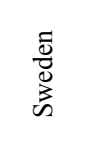 & $\begin{array}{l}\frac{n}{0} \\
\frac{\mathbb{E}}{\overline{0}} \\
\frac{ \pm}{0} \\
Z\end{array}$ & 饲 & 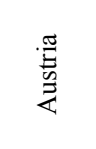 & 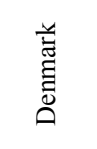 & 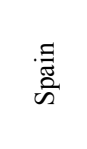 \\
\hline $\begin{array}{c}\text { Average } \\
\text { change rate } \\
\mathrm{Ef}_{\mathrm{C}}\end{array}$ & $\mathrm{Ef}_{\mathrm{DE}}$ & $\mathrm{Ef}_{\mathrm{FR}}$ & $\mathrm{Ef}_{\mathrm{GB}}$ & $\mathrm{Ef}_{\mathrm{IT}}$ & $\mathrm{Ef}_{\mathrm{SE}}$ & $\mathrm{Ef}_{\mathrm{NL}}$ & $\mathrm{Ef}_{\mathrm{FI}}$ & $\mathrm{Ef}_{\mathrm{AT}}$ & $\mathrm{Ef}_{\mathrm{DK}}$ & $\mathrm{Ef}_{\mathrm{ES}}$ \\
\hline $\begin{array}{c}\text { Average } \\
\text { change rate } \\
{[\%]}\end{array}$ & $-0.65 \%$ & $-0.95 \%$ & $-1.19 \%$ & $-0.05 \%$ & $0.67 \%$ & $-2.58 \%$ & $-3.24 \%$ & $-0.48 \%$ & $-0.62 \%$ & $0.39 \%$ \\
\hline
\end{tabular}

Source: Own calculation.

As can be seen from the results of the calculations, the number of patents (obtained from the EPO by enterprises belonging to the business enterprise sector that are assignees) per 1 million euros of the total intramural $\mathrm{R} \& \mathrm{D}$ expenditure in the business enterprise sector, increases from year to year on average by 
$0.67 \%$ in Sweden and $0.39 \%$ in Spain. The conclusion is that in these countries the long-term effectiveness of using resources for the $\mathrm{R} \& \mathrm{D}$ sector is increasing. While in the other examined countries, efficiency is reduced by the greatest extent in Finland (-3.24\%).

\section{DISCUSSION AND CONCLUSIONS}

The scope of this article was to evaluate the efficiency of R\&D expenditure from the patent activity point of view, which belongs to effects of $R \& D$ activity.

Among the 28 EU counties, 98.07\% of assignee patents granted by the EPO in the period of 19992013 are given to entities belonging to the business enterprise sectors of the leading countries, which include: Austria, Denmark, Finland, France, Germany, Italy, the Netherlands, Spain, Sweden and the United Kingdom. $1.93 \%$ of assignees belong to the remaining 18 countries of the UE. Hence, the ten leading countries were covered by the research. The first research question of the articles was: does the increase of $R \& D$ expenditure cause, in the long term, an increase in the patenting activity of the business enterprise sector? It was found that, in all leading countries, the average change rate in total intramural $R \& D$ expenditure in the business enterprise sector is positive which means that the amount of expenditure was increasing from year to year throughout the period 1999-2013. On the basis of the calculations, it was also found that the number of entities belonging to the business enterprise sector of the researched countries, which are assignees of patents granted by the EPO was increasing from year to year in the same research period. The conclusion is that the increase in total intramural expenditure on $\mathrm{R} \& \mathrm{D}$ activities in the business enterprise sectors of the ten leading EU countries causes increases in the patenting activity of the sector in the long term.

The second and main research question was: does the efficiency of R\&D expenditure, measured by the patent activity of the business enterprise sector, improve in the long term? Based on the research, it was found that the increase of total intramural $R \& D$ expenditure in the business enterprise sectors in all ten leading countries covered by the research is accompanied by an increase in the effectiveness of their use in patent activity only in two countries: Sweden and Spain. In the other eight countries there was a long-term decline in the effectiveness of the patent activity of the business enterprise sector. The research results also reveal that the creation of patents in the business enterprise sector in Germany is on average more than eight times less expensive than in Spain.

The main conclusion of this study is that the increase in patent activity of entities belonging to the business sector is achieved not only by an increase in expenditure on R\&D but also by the efficient and effective management of this activity. Hence, the rising patent activity of the business enterprise sector in the long term depends on the management of $R \& D$ activity in entities belong to that sector, rather than an increase in $R \& D$ spending. There is a greater need for strategic thinking, predicting the results of $R \& D$ activity, and the appropriate allocation of resources in development of the business enterprise sector, which, in turn, concern R\&D management.

\section{REFERENCES}

Davila, T., Epstein, M. \& Shelton, R. (2012). Making Innovation Work: How to Manage It, Measure It, and Profit from It. Upper Saddle River, NJ: FT Press.

Degraff, J. \& Quinn, E. (2007). Leading Innovation. New York: McGraw-Hill.

Doloreux, D. \& Parto, S. (2005). Regional Innovation Systems: Current Discourse and Challenges for Future Research. Technology in Society, 27, pp.133-154. 
Dyer, J., Gregersen, H. \& Christensen, C. (2011). The Innovator's DNA. Boston: Harvard Business Review Press.

Fichter, K. \& Hintermann, R. (2010). Leitfaden Innovationspotenzialanalyse. Oldenburg: Oldenburg University Publisher.

Freedman, D., Pisani, R. \& Purves, R. (2007). Statistics. New York: W. W. Norton \& Company.

Griliches, Z. (1990). Patent Statistics as Economic Indicators: A Survey. Journal of Economic Literature, 28, pp.16611707.

Griliches, Z., Pakes, A. \& Hall, B. (1986). The Value of Patents as Indicators of Inventive Activity. Boston: NBER.

Okon-Horodyńska, E. (2004). What with the National Innovation System? In Role of the Polish Science in the Growth of Economy Innovativeness (2004), ed. Okoń-Horodyńska, E. Warsaw: Polish Economic Society.

Schmookler, J. (1951). Invention and Economic Development. Philadelphia: University of Pennsylvania.

Schwab, K. Sala-i-Martin, X. (2015). The Global Competitiveness Report 2014-2015. Geneva: WEF Publisher.

Simmine, J. (2003). Innovation and Urban Regions as National and International Nodes for the Transfer and Sharing of Knowledge. Regional Studies, 37, pp.607-620, August/October.

Stern, S., Porter, M. \& Furman, L. (2000). The Determinants of National Innovative Capacity. Working Paper, No 7876 , Cambridge: National Bureau of Economic Research.

Triola, M., (2014). Essentials of Statistics. London: Pearson.

Verdes, A. (2006). Inventions and Globalization: Innovation Potential by Countries. Budapest: International Federation of Inventors' Associations.

Wisła, R. (2012). The Structure of Patenting Activity and the Broad Lines of Development of Technologies in High Technology Industries of the Selected Countries of the European Union. Actual Problems of Economics, 2(10), pp.44-51.

Wisła, R. (2014). Regional Patterns of Technical Knowledge Accumulation in the Countries of Central and Eastern Europe. Warsaw: Polish Scientific Publishers PWN. 